Research Article

\title{
Evaluation of Mustard Powder as Natural Ingredient to reduce Antimicrobial levels and Physichochemical properties in Beef
}

\author{
Amir Hosseinvand ${ }^{\star}$ and Adeleh Sorkhinejad ${ }^{2}$ \\ IDepartment of Agriculture, Islamic Azad University of Shahr-e-Qods branch, Tehran, Kalhor BLVD, Shahre Qods City, Tehran province, Iran \\ 2Department of Chemistry, Islamic Azad University of Karaj branch, Karaj, Iran
}

\section{Article Info \\ *Corresponding author: \\ Amir Hosseinvand \\ Department of Agriculture \\ Islamic Azad University of Shahr-e-Qods Branch \\ Tehran, Kalhor BLVD, Shahre Qods City Iran \\ Tel: +989123033161 \\ E-mail: Amir.Hosvnd@yahoo.com}

Received: February 2, 2019

Accepted: May 6, 2019

Published: May 13, 2019

Citation: Hosseinvand A, Sorkhinejad A. Evaluation of Mustard Powder as Natural Ingredient to reduce Antimicrobial levels and Physichochemical properties in Beef. Madridge J Food Technol. 2019; 4(1): 170-175. doi: 10.18689/mjft-1000126

Copyright: ( $\subset 2019$ The Author(s). This work is licensed under a Creative Commons Attribution 4.0 International License, which permits unrestricted use, distribution, and reproduction in any medium, provided the original work is properly cited.

Published by Madridge Publishers

\begin{abstract}
Nowadays, most of people would passion to using and purchase organic and natural foods without any artificial ingredients. Moreover, mustard is used in producing medicines, pickles, source of edible oils since ancient times, seasoning of meats and chicken. So the present study was undertaken to determine the chemical components of mustard powder, and then used it in grilled beef as a seasoning to improve sensory evaluation, and physicochemical properties, as well as inhibited Escherichia coli, Staphylococcus aureus and increased shelf life of meat. The results indicated that added mustard powder improving sensory evaluation of the grilled meat slices significantly, especially in odour, in the acceptability of meat treated with $2 \%$ level of mustard powder. Meanwhile, addition of mustard powder to fresh meat reduced the natural flora to undetectable levels at $4^{\circ}$ or $30^{\circ} \mathrm{C}$ till 2 days from storage. Application of mustard powder was able to reduce E.coli numbers to uncountable levels at zero time during keeping samples.

In view of $\mathrm{pH}$, TBA and TVN values, all of the grilled meat slices with added mustard powder decreased by increasing level on mustard powder concentration during storage times. Mustard powder at $2 \%$ level has antibacterial, anti-microflora, natural preserve spices in food, improved taste, smell and physical properties of meat and increased shelf life of meat. Finally mustard powder is acceptable to use as spice and natural ingredient to reduce antimicrobial loading in foodstuff. Further study in this area may be helpful for finding of new principle compound.
\end{abstract}

Keywords: Mustard powder; Antimicrobial; Physicochemical; Meat; E.coli.

\section{Introduction}

The most important food-borne diseases, it is caused by agents such as E.coli, Salmonella, and S.aureus that enter the body through the intake of contaminated food materials are one of the primary public health concerns in the world [1]. In the present study, application of yellow mustard seed (Sinapis alba L.) as natural ingredient was studied in beef. There is little published data in the literature on application of natural and functional antibacterial ingredients in food science. White and red meats were one of the principal food stuff in human meals. The mustard seed is a source of natural antioxidants such as; tocopherole, compounds of hydroxyl benzoic family, trihydroxy phenolic compounds like flavones, flavonols (kaemferol, isorahmnetin) and ascorbic acid which protect oil from rancidity in emulsion. Moreover, this plant can be a good source of active components such as, isothiocyanates, phenolics, dithiolthiones and dietary fiber [2-4]. Mustard powder contained higher amounts of protein $36.69 \%$ and oil $40.64 \%$. 
Moreover, oil of mustard seeds contained high amount of erucic acid $51.3 \%$, and the major dominant unsaturated fatty acids were, oleic acid followed by linoleic and linolenic acids.

The objective of the present research was to reduce bacterial loading of E.coli and Staphylococcus aureus in grilled beef with mustard powder as antibacterial seasoning, and then assessment of addition of yellow mustard powder on some physicochemical properties on beef.

\section{Materials and Methods}

\section{Chemical composition of mustard seeds powder}

The analysis of moisture, ash, total carbohydrates, crude protein, crude fiber and fat were determined for the dried mustard seeds powder is described by the Association of Official Agricultural Chemists [5].

\section{Determination of FA content}

Fatty acid content of samples was determined by GCŽ. CarloErba Fractovap after $\mathrm{KOH}$ methanol hydrolysis and $\mathrm{BF}$ derivation. Supelco wax 10 column capillary Ž3 length $15 \mathrm{~m}$, diameter $0.25 \mathrm{~mm}$, film thickness $25 \mathrm{~m}$. The temperature of the injector and detector was $225^{\circ} \mathrm{C}$ [6].

\section{Ground beef and mustard powder preparation}

Fresh beef was purchased from local butcher shop the day before each experiment. The meat was stored at $4^{\circ} \mathrm{C}$ over night. Also, all of the meats were kept at $-18^{\circ} \mathrm{C}$ for $3 \mathrm{~h}$, until the outer surface was frozen. Ground beef was prepared using aseptic procedures, sterile utensils and sanitized equipment. The meat was cut into $5 \times 5 \mathrm{~cm}$ pieces, each on equal $100 \mathrm{gm}$, and then held it $4^{\circ} \mathrm{C}$ for 1 hour. After that it was inoculated with bacterial strains and treatment with mustard powder. In the present study the Sinapis alba seed (yellow mustard) spicy were collected from local market in Tehran, Iran. The seed was cleaned and grained to get mustard powder rich with active components. Antibacterial effects of mustard powder were one by well diffusion method, whereas, it was showed antibacterial activity against E.coli \& Staph.aureus with 28 \& $22 \mathrm{~mm}$ zone inhibition, respectively.

\section{Sensory evaluation}

The fresh beef used was previously described. For control sample, $2 \mathrm{gm}$ salt was added to each piece. For treatment samples $2 \mathrm{gm}$ salt plus different concentrations of mustard flour with $0.5,1.0,1.5,2.0$ and $2.5 \%$ levels. All samples were cooked on grilled at $200^{\circ} \mathrm{C}$ until the internal temperature reached to $71^{\circ} \mathrm{C}$. Grilled meats were kept at $60^{\circ} \mathrm{C}$ until they were served to the panelists. Sixty staff at the food technology research institute who had received no formal training in sensory evaluation participated. Panelists were $30-60$ years old and $75 \%$ were female. Each panelist received three $10 \mathrm{gm}$ samples of grilled beef in a container coded with a randomly chosen three digit number, plus water. The panelists tasted samples and recorded the overall acceptability of each treatment product according to colour, smell, flavor and consistency. The experiments were repeated at least five times [7].

\section{Bacterial strains}

For this research, two reference strains Staphylococcus aureus ATCC 25923 and E.coli ATCC 25922 were obtained from microbial culture collection, Department of Microbiology, Faculty of Agriculture, Tehran University, Tehran, Iran. Strains were Activate on nutrient broth (NB) at $37^{\circ} \mathrm{C}$ for $24 \mathrm{~h}$.

\section{Effect of mustard powder on bacterial counts in meat slices}

This experiment was divided into two parts; first part meat slices were thawed at $4^{\circ} \mathrm{C}$ overnight, then adding $0.5,1.0,1.5,2.0$ and $2.5 \%$ levels of mustard powder and salt before grilling. Total count (natural flora) of each sample was evaluated before and after treatment (seasoning) and stored for 2 days at $4^{\circ} \mathrm{C}$ or $30^{\circ} \mathrm{C}$. Second part, grilled meat slices, then adding 0.5, 1.0, 1.5, 2.0 and $2.5 \%$ mustard powder and salt plus inoculation with $0.5 \mathrm{ml}(1 \times$ $10^{5} \mathrm{cfu} / \mathrm{ml}$ ) reference strains. All samples were kept in aluminum foul trays under sterilize conditions for 24 hours at $4^{\circ} \mathrm{C}$ or $30^{\circ} \mathrm{C}$. Total bacterial counts were determined periodically after $0,1,2$, 3 and 6 days according to the procedure mentioned by APHA [8]. In addition, salt was added in testifier samples.

\section{Physical properties}

pH value: $\mathrm{pH}$ value of meat product samples was examined according to the method as reported by Ockerman [9].

\section{Chemical properties}

Determination of total volatile bases Nitrogen (TVB-N): Total volatile nitrogen was determined according to the method described by Winton and Winton [10]. The milligrams of TVB-N per $100 \mathrm{gm}$ sample were obtained by number of milliliters of bound acid $\times 7.0$.

Determination of Thiobarbituric Acid Value (TBA): Malonaldehyde (the compound used as an index of lipid per oxidation) was determined following the procedure of Pearson et al. [11]. TBA value was expressed as mg malonaldehyde $/ \mathrm{kg}$ sample by using the following equation.

TBA value (Mg malonaldehyde/kg sample)=absorbance $\times 7.8$

\section{Statistical analysis}

The data obtained from treatments were analyzed by one-way ANOVA using 'Proc Mixed' (SAS 8.2, Cary, NC, USA). In all cases, the level of statistical significance was of $P<0.05$. SAS program was used to statistical analyzed [12]. LSD means comparisons were conducted with the duncan option in SAS.

\section{Results and Discussion}

\section{Physicochemical composition}

The proximate analysis of beef samples with and without mustard powder with different concentrations presented in table 1. Mustard powder is contained a large amounts of both protein and oil contents. It could be also observed that mustard flour is containing an adequate percentage of ash, dietary fiber and total carbohydrates [13-15].

The fatty acids composition of yellow mustard seeds oil was determined by gas chromatographic analysis, then presented the data in table 1 . It is clear from the result that 
erucic acid (C22:1) was most predominant fatty acids in mustard seed oil, which was represented as $\sim 51.03 \%$. Mustard oil rich in erucic acid is considered undesirable and indigestible for human or animal organisms. It could be remarked that mustard seed oil contained a little amounts from total saturated fatty acids determined with $\sim 6.93 \%$ as compared to the other edible oils. These results were shown in the study by Zheljazkov et al. [16] whereas it was recommended that the mustard oil has low saturated fat as compared to other cooking oils [17]. In contrary, the total unsaturated fatty acids in mustard seeds oil were considerable a high amount, which represented $\sim 85 \%$. The major types of unsaturated fatty acids were namely: Oleic, linoleic, linolenic and gadoleic acids. In addition, linoleic acid and linlolinic were the most prevalent unsaturated fatty acids, and it is the most important of the essential fatty acids. These results are in accordance with the data previously obtained $[15,18]$.

Table 1. Percentage of chemical composition and fatty acid of mustard flour content.

\begin{tabular}{|l|c|c|c|c|c|c|c|}
\hline \multirow{2}{*}{ Components \% } & \multicolumn{6}{|c|}{ Fatty acids \% (g/100 g) } \\
\cline { 3 - 8 } & & \multicolumn{2}{|c|}{ Saturated fatty acids } & Unsaturated fatty acids \\
\hline Moisture & 1.78 & Palmitic & C16:0 & 2.27 & Erucic & C22:1 & 51.03 \\
\hline & 2.27 & & & & & & \\
\hline Protein & 42 & Stearic & C18:0 & 0 & Palmitoleic & C16:1 & 0.04 \\
\hline Ash & 4.42 & Lignoceric & C24:0 & 0.94 & Oleic & C18:1 & 8.08 \\
\hline Crude oil & 40.64 & Arachic & C20:0 & 1.062 & Nervonic & C24:1 & 2.27 \\
\hline${ }^{*}$ Carbohydrate & 40.64 & Behenic & C22:0 & 1.58 & & & \\
\hline
\end{tabular}

${ }^{*}$ Carbohydrate is calculated by difference.

All components are determined on dry weight.

\section{Sensory attributes}

Sensory evaluation scores of the beef with and without mustard powder shown in table 2. In this table, color, smell, flavor, consistency and over all acceptability of grilled meat slice samples are shown as affected by the different concentrations of yellow mustard powder $(0.00 \%, 0.5 \%, 1.0 \%$, $1.5 \%, 2.00 \%$ and $2.50 \%$ ) and testifier samples. Along with the increase in mustard content from $0 \%$ to $2.0 \%$, all characteristics of sensory evaluation score improved considerably from 3.08 to 4.94. According to data, the sensory attributes has highly significant effects on smell of grilled meat slices were scored at $2.0 \%$ level of mustard powder. This result indicated to benefit of added yellow mustard as the strong flavoring component of meat slices. With the increase of mustard powder by $2.0 \%$, the mean of flavors core increased to 4.94. The application of heating treatment in grilled meat slices led into myrosinase enzyme activation, isothiocyanate reduction and thus reduction of pungent flavor in mustard powder. The results were not in line with the findings of Cserhalmi et al. [13], Ildiko et al. and [18], Milani et al. [19]. They stated that, mayonnaise, containing mustard powder gave a higher smell in comparison with the samples containing mustard powder and control sample. They explained that in higher concentrations of the yellow mustard powder this proliferation causes a pungent flavor in mayonnaise. It was a result of an increase in the content of isothiocyanate, following the activity of myrosinase enzyme in mustard powder. So use of heating treatment and the production of mustard powder improve the smell of final product.

Table 2. Sensory attributes of grilled meat slices with mustard powder \%.

\begin{tabular}{|c|c|c|c|c|}
\hline Sample & Colour & Smell & Flavour & Consistency \\
\hline 0 & $3.08 \pm .03$ & $3.08 \pm .03$ & $3.08 \pm .03$ & $3.54 \pm 0.20$ \\
\hline 0.5 & 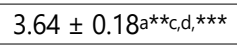 & 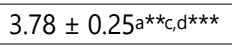 & $3.58 \pm 0.25$ & 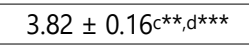 \\
\hline 1 & 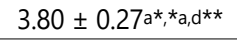 & $3.50 \pm 0.24 c, d \star \star \star$ & $3.82 \pm 0.28 \mathrm{~d}^{\star \star *}$ & $3.64 \pm 0.22 c^{\star}, \mathrm{d}^{\star \star}$ \\
\hline 1.5 & $4.42 \pm 0.16 \mathrm{a}, \mathrm{b}, \mathrm{e}^{\star \star * *}$ & $4.66 \pm 0.18 \mathrm{a}, \mathrm{b}, \mathrm{c}, \mathrm{e}^{* * *}$ & $4.00 \pm 0.28^{a \star \star \star, d \star \star}$ & $4.38 \pm 0.18^{a, e \star * \star, b *, c * \star}$ \\
\hline 2 & $4.76 \pm 0.19 \mathrm{a}, \mathrm{b}, \mathrm{c}, \mathrm{e}^{\star \star \star}$ & $4.94 \pm 0.04 a, b, c, e^{* \star *}$ & $4.66 \pm 0.1 \mathrm{a}, \mathrm{b}, \mathrm{e},{ }^{\star \star \star}, \mathrm{c}, \mathrm{k \star}$ & $4.30 \pm 0.18^{a, b, c, e^{\star \star *}}$ \\
\hline 2.5 & 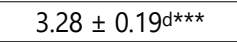 & $3.34 \pm 0.17 \mathrm{~d} * \star *$ & $3.40 \pm 0.18$ & 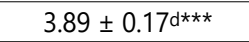 \\
\hline
\end{tabular}

Values are expressed as means \pm SE. (Standard Error of the Mean) of the three replicates).

a: significantly different from the control group; b: significantly different from the concentration $5 \%$; c: significantly different from the concentration $1 \%$; d: significantly different from the concentration $1.5 \%$; e: significantly different from the concentration $2 \%$.

Asterisk indicate the level of significance $\left({ }^{*} \mathrm{p}>0.05 ;{ }^{* *} \mathrm{p} 0.01{ }^{* * *} \mathrm{p}>0.001\right.$.).

\section{Influence of mustard powder on antimicrobial loading activities}

From the obtained results in figure 1 , fresh meat was seasoning with mustard flour at 1.5 and $2.0 \%$ levels, it was able to reduce the natural flora to undetectable levels until two days of storage at different temperatures, while the control sample spoilage after $24 \mathrm{~h}$ at $30^{\circ} \mathrm{C}$. It is clearly from this study, when adding mustard powder to fresh meat slices; this preserved it from contamination and reduced the natural microflora for 2 days before cooked, at any temperature. This finding is in mutual and good agreement with Milani et al. [19], they reported that the increase in amount of mustard powder in mayonnaise leads into decrease in microbial population as compare as to control sample. It showed a decrease in microbial population with $68 \%$ in mayonnaise that containing $1.5 \%$ mustard powder. Also, Nadarajah et al.
[20] concluded that, the natural anaerobic microflora in meat treated with $10 \%$ mustard powder was significantly lower on days 3, 12 and 21 storage as compared to control sample.

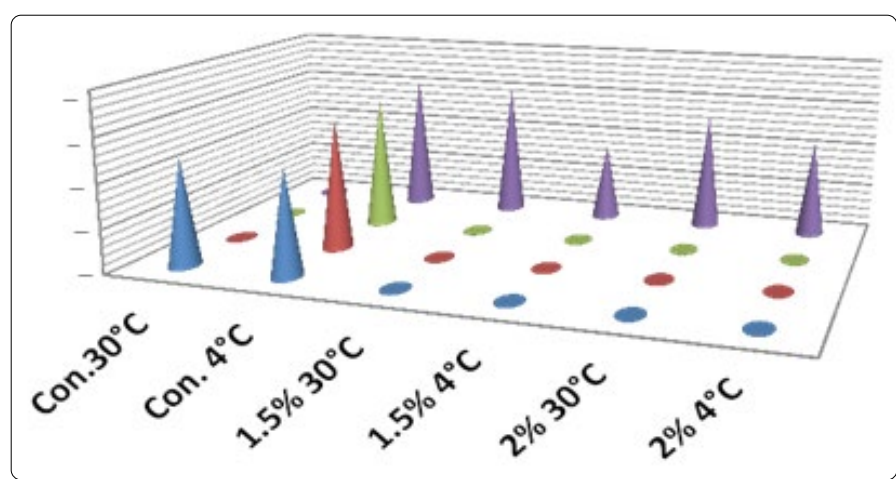

Figure 1. Effect of seasoning by mustard powder on the natural flora present in meat slices. 
The antimicrobial effects of mustard powder on the each E.coli or S.aureus when inoculated at $3.6 \mathrm{Log} \mathrm{cfu} / \mathrm{g}$ in meat slices before grilled (as shown in figure 2). Mustard powder 1.5 and $2 \%$ levels were able to reduce E.coli number to uncountable levels at zero time and till 3 days at $4^{\circ} \mathrm{C}$. The same effect was scored by mustard powder at $2 \%$ level against S.aureus. Meanwhile, used low initial 3 log cfu/gm of E.coli 0157: $\mathrm{H} 7$ was reduced to undetectable level after 18,12 and 3 days with $5,10,20 \%$ mustard flour the ground beef [21]. They also concluded that it is possible to use mustard powder at levels of $>5-10 \%$ to eliminate E.coli $0157: \mathrm{H} 7$ in fresh ground beef [21]. Inoculated $7.5 \mathrm{log}$ cfu/g of E.coli with $4.4 \%$ (W/W) deodorized mustard powder was surface applied and monitored 80 days. At 21 days bacteria was reduced by $3 \log$ $\mathrm{cfu} / \mathrm{g}$ as compared to control sample to only a $1 \mathrm{log} \mathrm{cfu} / \mathrm{g}$ were reduction from cells [19]. They were summarized that, the higher concentration of yellow mustard, led to less the microbial population and the longer the shelf life of mayonnaise. At this present study cells of S.aureus were less significant affect by mustard powder at $1.5 \%$ level than E.coli, and it was showed that it reduced in their number by 1 log $\mathrm{cfu} / \mathrm{gm}$ within 2 days at $4^{\circ} \mathrm{C}$. It is similarity to the study by Mohamed Esa [22] who found the good antibacterial effect from mustard against S.aureus. Meanwhile, gram-positive bacteria of S.aureus was found to be less susceptible to mustard powder in meat than E.coli. These results are not accordance with findings of other investigations [23], who pointed that, the gram-positive bacteria of S.aureus was found to be more susceptible to spice samples, and explained this due to their structural features, are more susceptible to phenolic compounds than gram negative bacteria.

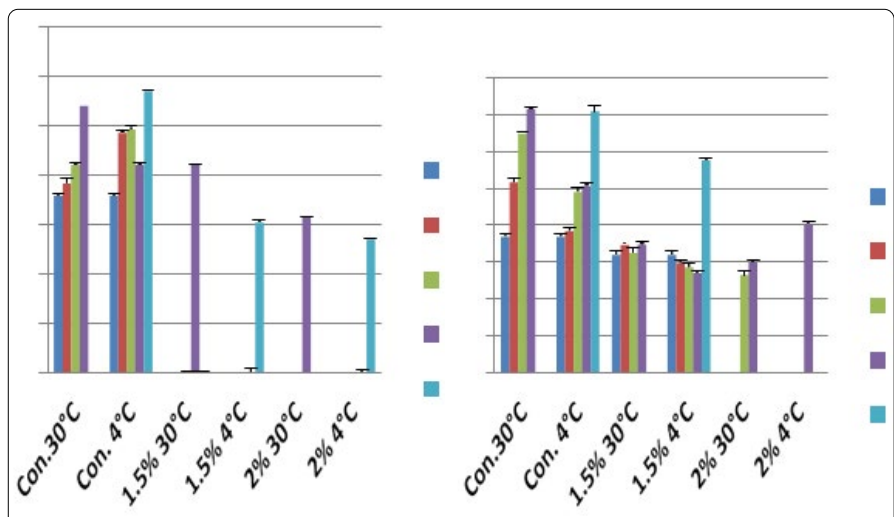

Figure 2. Effect of seasoning by mustard flour on the survival of inoculated bacteria in grilled meat slice.

\section{pH, TBA and TVN values}

As well as, the results of $\mathrm{pH}, \mathrm{TBN}$ and TVN measurement are showed in tables $3-5$. The $\mathrm{pH}$ in grilled meat slices inoculated with E.coli was ranged from 5.9 to 6.2 at $4{ }^{\circ} \mathrm{C}$ and $30^{\circ} \mathrm{C}$ were with $1.5 \%$ and $2 \%$ levels of mustard Powder. These results were not significant difference $(P<0.05)$ than control sample. These results nearly agree with the results were scored by Shedeed [24], with value 6.10, and with value of 6.15 [25]. The lowest $\mathrm{pH}$ was revealed in grilled slices at $4^{\circ} \mathrm{C}$ treated with $1.5,2 \%$ mustard powder till 6 days of storage and reached to 5.3 , except samples kept at $30^{\circ} \mathrm{C}$ were spoilage after 6 days were shown in table 5 . The decrease in $\mathrm{pH}$ value may be attributed to the breakdown of glycogen with the formation of lactic acid and, Poultry meat with a pH below 5.8 had a pale color. In conclusion mustard powder 1.5 and $2 \%$ levels used to keep the $\mathrm{pH}$ of grilled in ideal state till 6 days storage at $4^{\circ} \mathrm{C}$. This result could be used also if the meat was exposed to infect with pathogens. At this study, samples were treated by Staph. aureus plus mustard powder shown the idea $\mathrm{pH}$ ranged from(6.0-6.3) except, samples kept at $30^{\circ} \mathrm{C}$ were increase in $\mathrm{pH}(6.2-6.7)$ during the storage time. The increase of $\mathrm{pH}$ may be due to the partial proteolysis However, the ideal $\mathrm{pH}$ for meat is between 5.8 and 6.3 [26]. The meat with higher $\mathrm{pH}$ had dark color and has a great risk on human health. The TBA was lowest significant value ranged from 0.22 to 0.62 after 3 day of incubation at $30^{\circ} \mathrm{C}$ and $4^{\circ} \mathrm{C}$; this result was the same obtained result from control samples. While the TBA value 2.5-1.9 were scored level higher than ideal value in grilled meat without any treatment. Moreover, TBA ( $\mathrm{mg} \%$ ) in the grilled meat slices were decreased to the lowest significant value (0.62) at $2 \%$ mustard powder, $30^{\circ} \mathrm{C}$ and $4^{\circ} \mathrm{C}$ till 6 days as compare to control sample (1.6). On the other hand, lower results were scored by Afifi-Jehan and Youssef Fatma $[25,27]$ were ranged $0.119 \mathrm{mg}$ and $\% 0.09 \mathrm{mg} \%$ respectively. The oxidative rancidity in meat was evaluated by measuring malonaldehyde in fat meat with an improved thiobarbituric acid (TBA) assay with antioxidant protection [28]. Value of TVN ( $\mathrm{mg} \%$ ) in grilled meat slices treated with $2 \%$ mustard powder were decreased at different temperature. Furthermore, sample with $2 \%$ mustard powder kept at $4^{\circ} \mathrm{C}$ and inoculated with E.coli has low TVN value ranged from 5.2, 7.3 after storage at 3,6 days respectively. Higher results were obtained by Afifi-Jehan and Youssef Fatma [25,27] with TVN value of 9.11 and 13.87 ( $\mathrm{mg} \%$ ). Ammonia is one of the most spoilage end products in contaminated meat; it is an indicator for amino acid degradation by bacteria. So, it is directly pointer for spoilage odors and flavors [9,29-31]. The grilled meat without seasoning by mustard powder showed highly significant increase in physical properties after 3 days of storage, and spoilage after 6 days $[10,12,24,32,33]$.

Table 3. Physical properties of grilled meat slices with mustard flour and E.coli.

\begin{tabular}{|c|c|c|c|c|c|c|c|c|c|c|c|c|c|}
\hline \multirow{2}{*}{\multicolumn{2}{|c|}{$\begin{array}{c}\text { Samples } \\
0\end{array}$}} & \multicolumn{4}{|c|}{$\mathrm{pH}$} & \multicolumn{4}{|c|}{ TBA\% } & \multicolumn{4}{|c|}{ TVN\% } \\
\hline & & 3 & 6 & LSD & 0 & 3 & 6 & LSD & 0 & 3 & 6 & LSD & \\
\hline \multirow[t]{3}{*}{$30^{\circ} \mathrm{C}$} & Control & $6.06 \mathrm{Aa}$ & $6.20 \mathrm{Aa}$ & $6.25 \mathrm{Aa}$ & 0.22 & $0.32 \mathrm{Ab}$ & $0.43 \mathrm{Ab}$ & $1.64 \mathrm{Aa}$ & 0.23 & $8.40 \mathrm{Ac}$ & $10.50 \mathrm{Ab}$ & 14.00Aa & 0.06 \\
\hline & $1.5 \%$ & $6.01 \mathrm{Ab}$ & 6.06ABab & $6.20 \mathrm{ABa}$ & 0.17 & $0.22^{\mathrm{Bb}}$ & $0.29 \mathrm{BCb}$ & $0.94 \mathrm{Ca}$ & 0.10 & $6.65 \mathrm{BC}$ & $9.10^{\mathrm{Bb}}$ & $11.55 \mathrm{Ba}$ & 0.98 \\
\hline & $2 \%$ & 5.99Ab & 6.02ABab & $6.09 \mathrm{BCa}$ & 0.09 & $0.18 \mathrm{Cb}$ & $0.23 \mathrm{cb}$ & $0.87 \mathrm{CDa}$ & 0.05 & $4.90 \mathrm{cc}$ & $5.95 \mathrm{cb}$ & $8.05 \mathrm{Da}$ & 1.27 \\
\hline \multirow[t]{3}{*}{$4^{\circ} \mathrm{C}$} & Control & $6.06 \mathrm{Ab}$ & 6.09ABab & 6.19ABa & 0.12 & $0.33 \mathrm{Ab}$ & $0.38 \mathrm{ABb}$ & $1.12^{\mathrm{Ba}}$ & 0.06 & $8.40 \mathrm{Ac}$ & $9.10^{\mathrm{Bb}}$ & $11.55 \mathrm{Ba}$ & 0.90 \\
\hline & $1.5 \%$ & 6.01Aa & $6.02^{\mathrm{ABa}}$ & $6.07 \mathrm{BCa}$ & 0.14 & $0.217^{\mathrm{Bb}}$ & $0.27 \mathrm{Cb}$ & 0.77DEa & 0.08 & $6.65 \mathrm{BC}$ & $8.40^{\mathrm{Bb}}$ & $10.50^{C a}$ & 0.90 \\
\hline & $2 \%$ & 5.99Ab & $5.99 \mathrm{Bb}$ & $6.00 \mathrm{Ca}$ & 0.01 & $0.18 \mathrm{cb}$ & $0.219 \mathrm{Cb}$ & 0.64Еа & 0.07 & $4.90 \mathrm{cb}$ & $5.25 \mathrm{Cb}$ & 7.35Еа & 0.57 \\
\hline LSD & & 0.10 & 0.44 & 0.124 & & 0.01 & 0.09 & 0.15 & & 0.36 & 1.13 & 0.51 & \\
\hline
\end{tabular}


Table 4. Physical properties of grilled meat slices with mustard flour and Staph.aureus.

\begin{tabular}{|c|c|c|c|c|c|c|c|c|c|c|c|c|c|}
\hline \multirow{2}{*}{\multicolumn{2}{|c|}{$\begin{array}{c}\text { Samples } \\
0\end{array}$}} & \multicolumn{4}{|c|}{$\mathrm{pH}$} & \multicolumn{4}{|c|}{ TBA\% $\%$} & \multicolumn{4}{|c|}{ TVN\% } \\
\hline & & 3 & 6 & LSD & 0 & 3 & 6 & LSD & 0 & 3 & 6 & LSD & \\
\hline $30^{\circ} \mathrm{C}$ & Control & $6.06^{\mathrm{Aa}}$ & 6.21ABa & $6.25 \mathrm{Ba}$ & 0.22 & $0.33 A c$ & 0.76ADEb & 1.64Aa & 0.23 & $8.4 \mathrm{Ac}$ & $10.5 \mathrm{Ab}$ & $14.0^{\mathrm{Ab}}$ & 0.23 \\
\hline & $1.5 \%$ & $6.02^{A C}$ & $6.27 \mathrm{Ab}$ & $6.85 \mathrm{Aa}$ & 0.13 & $0.28 \mathrm{Bc}$ & $0.44 \mathrm{Cb}$ & $1.607 \mathrm{BCa}$ & 0.15 & $7.3 \mathrm{BC}$ & $9.8^{A B b}$ & 11.9Ba & 0.23 \\
\hline & $2 \%$ & $6.01^{\mathrm{Ab}}$ & $6.19 A B b$ & $6.73^{\mathrm{Aa}}$ & 0.23 & $0.22^{\mathrm{Cb}}$ & $0.28 \mathrm{Db}$ & $0.93 \mathrm{CDa}$ & 0.06 & $5.9 \mathrm{cc}$ & $7.0 \mathrm{Db}$ & 9.8Da & 0.40 \\
\hline $4^{\circ} \mathrm{C}$ & Control & $6.06^{\mathrm{Ab}}$ & $6.09 \mathrm{BCab}$ & $6.20^{\mathrm{Ab}}$ & 0.12 & $0.33^{A b}$ & $0.38 \mathrm{CDb}$ & $1.12^{\mathrm{Ba}}$ & 0.06 & $8.4 \mathrm{Ac}$ & $9.1 \mathrm{BCb}$ & $11.5^{\mathrm{Ba}}$ & 0.90 \\
\hline & $1.5 \%$ & $6.02^{\mathrm{Aa}}$ & $6.03 \mathrm{Ca}$ & $6.09 \mathrm{Ba}$ & 0.08 & $0.28 \mathrm{BC}$ & $0.57 \mathrm{Bb}$ & $0.84 \mathrm{Da}$ & 0.11 & $7.3 \mathrm{BC}$ & $8.7 \mathrm{Cb}$ & $10.8^{\mathrm{Ca}}$ & 1.30 \\
\hline & $2 \%$ & $6.01 \mathrm{Ac}$ & $6.03 \mathrm{Cb}$ & $6.05 \mathrm{Ba}$ & 0.02 & $0.22 \mathrm{Cb}$ & $0.25 \mathrm{~Eb}$ & 0.62Еа & 0.09 & $5.9 \mathrm{cc}$ & $6.6 \mathrm{Db}$ & 8.4Ea & 0.57 \\
\hline LSD & & 0.08 & 0.14 & 0.28 & & 0.04 & 0.12 & 0.15 & & 0.41 & 0.95 & 0.36 & \\
\hline
\end{tabular}

Table 5. Physical properties of grilled meat slices plus mustard flour.

\begin{tabular}{|c|c|c|c|c|c|c|c|c|c|c|c|c|c|}
\hline \multirow{2}{*}{\multicolumn{2}{|c|}{$\begin{array}{c}\text { Samples } \\
0\end{array}$}} & \multicolumn{4}{|c|}{$\mathrm{pH}$} & \multicolumn{4}{|c|}{ TBA\% } & \multicolumn{4}{|c|}{ TVN\% } \\
\hline & & 3 & 6 & LSD & 0 & 3 & 6 & LSD & 0 & 3 & 6 & LSD & \\
\hline $30^{\circ} \mathrm{C}$ & Control & $5.46 \mathrm{Ab}$ & $5.80^{\mathrm{Aa}}$ & Sp & 0.20 & $0.07 \mathrm{Ab}$ & $2.59 \mathrm{Aa}$ & Sp & 0.14 & $11.20^{A b}$ & 41.30Aa & Sp & 1.58 \\
\hline & $1.5 \%$ & $5.26^{\mathrm{Bb}}$ & $5.31 \mathrm{Ca}$ & Sp & 0.03 & $0.06 \mathrm{Ab}$ & $1.95 \mathrm{Ca}$ & $S p$ & 0.011 & $9.80^{\mathrm{Bb}}$ & $32.20 \mathrm{Ca}$ & $S p$ & 1.58 \\
\hline & $2 \%$ & $5.10^{\mathrm{Bb}}$ & 5.13Еа & Sp & 0.01 & $0.04 \mathrm{Bb}$ & $1.72 \mathrm{Da}$ & $\mathrm{Sp}$ & 0.06 & $8.40 \mathrm{cb}$ & $24.85 \mathrm{Da}$ & Sp & 1.68 \\
\hline $4^{\circ} \mathrm{C}$ & Control & $5.46 \mathrm{Ab}$ & $5.71 \mathrm{Ba}$ & $\mathrm{Sp}$ & 0.20 & $0.07 \mathrm{Ab}$ & $2.27 \mathrm{Ba}$ & $S p$ & 0.481 & $11.20^{\mathrm{Ab}}$ & $34.30^{\mathrm{Ba}}$ & $S p$ & 1.58 \\
\hline & $1.5 \%$ & $5.26 \mathrm{Ba}$ & $5.24 \mathrm{Da}$ & Sp & 0.03 & $0.06 \mathrm{Ab}$ & 1.268 Еа & $\mathrm{Sp}$ & 0.064 & $9.80^{\mathrm{Bb}}$ & $25.90 \mathrm{Da}$ & Sp & 1.58 \\
\hline & $2 \%$ & $5.10^{\mathrm{Ba}}$ & $5.12^{\mathrm{Fa}}$ & $\mathrm{Sp}$ & 0.01 & $0.04 \mathrm{Ab}$ & 1.10Еa & $S p$ & 0.225 & $8.40 \mathrm{Cb}$ & 20.30Еa & $S p$ & 1.12 \\
\hline LSD & & 0.18 & 0.01 & - & & 0.01 & 0.22 & - & & 1.017 & 1.368 & - & \\
\hline
\end{tabular}

Sp: Spoil age sample.

\section{Conclusion}

From the results of the present work, it can be concluded that mustard powder at 1.5 and $2.0 \%$ levels possessed good antimicrobial activity against natural microflora present in fresh meat, and reduced bacteria to undetectable levels until two days of storage at different temperatures, while the testifier sample was spoilage after $24 \mathrm{~h}$ at $30^{\circ} \mathrm{C}$. Moreover, at 1.5 and $2 \%$ levels from mustard powder were able to reduce E.coli number to uncountable levels at zero time and till 3 days of storage at $4^{\circ} \mathrm{C}$, the same effect was scored by mustard powder 2\% level against Staph.aureus.

\section{References}

1. Tan SL, Lee HY, Abu Bakar F, Abdul Karim MS, Rukayadi Y, Mahyudin NA. Microbiological quality on food handlers' hands at primary schools in Hulu Langat District, Malaysia. Int Food Res J. 2013; 20(5): 2973-2977.

2. Hendrix KM, Morra MJ, Lee HB, Min SC. Defatted mustard seed mealbased biopolymer film development. Food Hydrocoll. 2012; 26(1): 118125. doi: 10.1016/j.foodhyd.2011.04.013

3. Honda T, Tatsuzawa F, Kobayashi N, et al. Acylated anthocyanins from the violet-blue flowers of Orychophragonus violaceus. Phytochemistry. 2005; 66(15): 1844-1851. doi: 10.1016/j.phytochem.2005.05.026

4. Kirca A, Ozkan M, Cemeroglu B. Effects of temperature, solid content and $\mathrm{pH}$ on the stability of black carrot anthocyanins. Food Chem. 2007; 101(1): 212-218. doi: 10.1016/j.foodchem.2006.01.019

5. Association of Official Agricultural Chemists. Official Method of Analysis. AOAC, USA: Washington. 2000.

6. Xu XQ, Beardall J, Hallam ND. Modification of fatty acid composition in halophilic anthracitic microalgea. Phytochemistry. 1998; 49(5): 1249-1252.

7. AMSA. Research Guidelines for Cookery, Sensory Evaluation and Instrumental Tenderness Measurements of Fresh Meat. American Meat Science Association. Chicago, USA. 1995.

8. APHA. APhA Committees for 1971-1972. 1971.

9. Ockerman HW. Quality control of Post-Mortem Muscle Tissue. Department of Animal Sciences. The Ohio State University; Columbus, OH, USA. 1985.
10. Winton $A L$, Winton $K B$. Oxide distillation volumetric method for the determination of volatile nitrogen. In: Wikysons J (ed). The Analysis of Food. New York, Chapman and Hull, London. 1958: 840.

11. Pearson D, Egan H, Kirk RS, Sawyer R. Pearson's Chemical Analysis of Foods. Longman Scientific \& Technical. 1987.

12. SAS. User's Guide. SAS Institute, Cary, NC. 2001.

13. Cserhalmi Z, Markus Z, Czukor B, Baráth A, Toth M. Physico-chemical properties and food utilization possibilities of RF-treated mustard seed. Innov Food Sci Emerg Technol. 2000; 1(4): 251-254. doi: 10.1016/S14668564(00)00028-X

14. Sen $M$, Bhattacharyya D. Nutritional effects of a mustard seed protein on growing rats. Int J Food Sci Technol. 2003; 38(2): 225-232. doi: 10.1046/j.1365-2621.2003.00660.x

15. Sharma S, Singh J, Munshi GD, Munshi SK. Effect of biocontrol agents on lipid and protein composition of Indian mustard seeds from plants infected with Alternaria species. Archives of Phytopathology and Plant Protection. 2010; 43(6): 589-596. doi: 10.1080/03235400801972350

16. Zheljazkov VD, Vick B, Ebelhar MW, Buehringd N, Astatkie T. Nitrogen applications modify seed and oil yields and fatty acid composition of winter mustard. Ind Crops Prod. 2012; 36(1): 28-32. doi: 10.1016/j. indcrop.2011.08.002

17. Kanrar S, Venkateswari J, Dureja P, Kirti PB, Chopra VL. Modification of erucic acid content in Indian mustard (Brassica juncea) by up regulation and down-regulation of the Brassica juncea Fatty Acid Elongation1 (BjFAE1) gene. Plant Cell Rep. 2005; 25(2): 148-155. doi: 10.1007/s00299005-0068-3

18. Ildikó SG, Klára KA, Marianna TM, Ágnes B, Zsuzsanna MB, Bálint C. The effect of radio frequency heat treatment on nutritional and colloidchemical properties of different white mustard (Sinapis alba L.) varieties. Innov Food Sci Emerg Technol. 2006; 7(1-2): 74-79. doi: 10.1016/j. ifset.2005.06.001

19. Milani MA, Mizani M, Ghavami M, Eshratabadi P. Comparative analysis of antimicrobial characteristics of mustard paste and powder in mayonnaise. European Journal of Experimental Biology. 2014; 4(2): 412-418.

20. Nadarajah $\mathrm{D}, \mathrm{Han} \mathrm{JH}$, Holley RA. Used of mustard flour to inactivate Escherichia coli 0157:H7 in ground beef under nitrogen flushed packing. Int J Food Microbiol. 2005; 99(3): 257-267. doi: 10.1016/j.jiffoodmicro.2004.08.018

21. Nilson AM, Richard A, Holley A. Use of deodorized yellow mustard powder to control Escherichia coli 0157:H7 in dry cured Westphalian ham. Food Microbiol. 2012; 30(2): 400-407. doi: 10.1016/j.fm.2011.10.016 
22. Mohamed Esa SAR, Thangaraj $S$, Salique $S M$, Khan KF, Natheer SE. Antimicrobial and Biochemical Analysis of Some Spices Extract against Food Spoilage Pathogens. Internet Journal of Food Safety. 2010; 12: 71-75.

23. Ouattara B, Simard RE, Holley RA, Piette GJP, Begin A. Antibacterial activity of selected fatty acids and essential oils against six meat spoilage organisms. Int J Food Microbiol. 1997; 37(2-3): 155-162.

24. Shedeed NA. Evaluation of Microwave cooking of chicken meat. M.V.Sc. Thesis Faculty of Agric. Cairo University. 1999.

25. Afifi-Jehan SA. Chemical studies on some poultry meat products. M.V.Sci. Thesis Faculty of Vet. Med, Zagazig University. 2000.

26. Pearson AM, Gillette TA. Processed meats. 3rd edition. New York (NY): Springer; 1996.

27. Youssef Fatma E. Chemical profile of some frozen poultry meat. ph.D. Thesis(Meat hygiene). Faculty of .Veterinary Medicine. Benha University. 2013.
28. Abdel-Kader ZM. Lipid oxidation in chicken as affected by cooking and frozen storage. Nahrung. 1996; 40(1): 21-24. doi: 10.1002/food.19960400106

29. Gill CO. Meat spoilage and evaluation of potential storage life of fresh meat. J Food Prot. 1983; 46(5): 444-452. doi: 10.4315/0362-028X-46.5.444

30. Kanemaru K, Miyamoto T. Inhibitory effects on the growth of several bacteria by brown mustard and Allyl isothiocyanate. Nippon Shokuhin Kogyo Gakkaishi. 1990; 37(10): 823-829. doi: 10.3136/nskkk1962.37.10_823

31. Mayerhauser CM. Survival of enterohemorrhagic Escherichia coli O157:H7 in retail mustard. J Food Prot. 64(6): 783-787.

32. Sharma HK, Ingle S, Singh C, Sarkar BC, Upadhyay A. Effect of various process treatment conditions on the allyl isothiocyanate extraction rate from mustard meal. J Food Sci Technol. 2012; 49(3): 368-372. doi: 10.1007/ s13197-011-0282-7

33. Zhang Y, Yao S, Li J. Vegetable-drived isothiocyanates: antiprolierative activity and mechanism of action. Proc Nutr Soc. 2006; 65(1): 68-75. 